\title{
THE MECHANISM OF ELIMINATION OF BACTERIA FROM THE RESPIRATORY TRACT.
}

\author{
By Antiun L. Bloomfinid, M.D., \\ BALTHONE. \\ (From the Biologieal Division of the Medical Clinic, Johns Hopkins Hospital and \\ Medical School.).
}

As long ago as 1808, Lister ${ }^{1}$ noted that penetration of the lung by a fractured rib did not lead to infection of the pleural cavity even though the latter was brougbt in contact with the outer world by means of the inspired air. This observation was eventually followed by systematic studies which showed that in health the lungs are entirely or almost entirely bacteria-free, and a similar state of affairs was found to exist in the deeper nasal passages. The means whereby this condition of relative sterility is maintained has been carefully worked out, but the possibility of a similar protective mechanism in the mouth does not seem to have been entcrtained by those interested in the contiguous portions of the air passages. On the contrary, it has been generally assumal that the buecal cavity may be likened to an open Petri plate filled with a medium favorable for any cntcring bacteria, and superficial support for this idea comes from the actual identification of numerous varicties of organisms both saprophytic and pathogenic in cultures made from the mouth.

In the coursc of experiments made in the past three years wc have been ablc to show that despite the presence of a profusc indigenous flora the mouth is as adequately protected against the colonization of foreign bacteria as are the lungs or deeper nasal passages. It is the present purpose, therefore, to revicw what information is at hand about the whole question of the protective mechanism of the upper air passages and to indicate its significance in relation to the spread of infectious disease. Onc may consider in the case of each of the various regions (mouth, nasal passages and lungs) the following factors of possible importance: (a) anatomic conditions; (b) the flushing mechanism; (c) bactericidal action of secretions; (d) reaction of secretions; (c) the antagonistic action toward invaders of the indigenous flora, and $(f)$ phagocytosis.

The Protective Mechanism of the Mouth. As will be seen later, the prescnce of bacteria is avoided in the case of the nose and lungs largely by anatomic conditions which prevent the entry of organisms into these regions. It is of interest that the anatomic structure of the mouth does not in itself seem designed to prevent invasion. Inasmuch as the function of the mouth, as entrancc to the alimentary canal, makes it impossible to avoid the con- 
stant introduction of bacteria, a mechanism has been developed which acts by elimination rather than by filtration. But beforc discussing the details of this mechanism we may outline briefly the demand made upon it as wcll as what is actually accomplished by it. A host of forcign organisms is continually entering the buccal cavity. Of these the largest element is that carried in with food and drink. Milk, for example, usually contains many organisms, and various kinds of food, such as cheese, are swarming with bacteria and moulds. Fingers, eigarettes, stamps, and in the case of children, foreign objects of all sorts with bacterial content varying in kind and in extent, also make their way into the mouth, and finally a smaller number of organisms is constantly being inhaled. But if repeated throat cultures are made in normal pcople one finds not the diverse and variable flora which would be expected but a relatively simple and constant one. Revealed by acrobic methods there are a fcw predominating groups: The non-lıcmolytic streptococei, tle Gram-ncgative eocei, diphtheroids and stapliylococei-none of them organisms which are abundantly present in food or in the air. In addition one may find a miscellaneous group of transient bacteria which are present only for brief periods of time and are clearly intercepted by the culture swab in their passage tlirougl the mouth. Foreign pathogenic organisms are rarely found over loug periods of time save when associated with a local foeus of infection. In summary then there is cvidently a rapicl and effective climination of the horde of ineoming organisms whereby they are segregated from thenormal indigenous flora.

An analysis of this proccss of elimination indicates that it is accomplished mainly by a system of flusling which operates in two ways: In the first place the gross act of swallowing propels the major portion of ingested material by forcible contractions of the muscular masses of tongue and pharymx directly into the esophagus. If a suspension of charconl or a solution of a dye is swallowed there is intense strining of the dorsum of the tonguc, of the palate and of the checks, but little or none of thic sublingual space, tonsils or upper pharynx. ${ }^{2}$ Furthermore, if a suspension of bacteria containing many million organisms per cubic centimeter is ingested and cultures arc then made from various sites in the mouth and throat, rclatively few colonics are recovered, and these are confined largely to the tonguc. ${ }^{3}$ In onc such experiment nine colonies of the organism introduced grew in the culture from thic pharynx and less than fifty were obtained from the tonsils. The swallowing mechanism operates therefore toward a rapid and direct removal of material without any clurning action or tendency towarl unneecssary contamination of the whole mouth cavity and without forcible implantation of many bacteria upon the mucous membranes. 
In association with the above erude system of flushing a more lighly organized mode of elimination may be demonstrated. If foreign particles or bacteria are implantcd directly on the mucous membrancs of the tongue, tonsil or pharynx it is found that they ean no longer be readily dislodged. 'They adherc firmly in thic tenacious mucus and are not removed by such procedures as rinsing or gargling. But once fastened in this way the particle or organism is drawn rapidly backward by a series of suction eurrents and is swallowed. The patlss of thesc currents are quite dircet. Bacteria implanted on the right side of the tongue, for example, travel backward on this side without erossing the midline and without contaminating the tonsil unless the latter is proninent; from the tonsil or plarynx they always movc toward the esophagus -never forward into the mouth. ${ }^{23}$

The net effeet of the operation of this mcehanisin we have tested by experimentally introducing various bacteria into the moutlss of men. The general result has been that within twenty-four hours such organisms as the colon bacillus, staplyylococcus, influenta bacillus, streptococcus and Fricdlander bacillus are entirely eliminated. ${ }^{4}$ It would appear, therefore, that the clance foreign pathogen introduced by natural means woukd ordinarily bave but little clinnce of colonizing.*

In this connection a word may be said about the function of the tonsils. As pointed out by various writers, for examplc, Crowe, ${ }^{5}$ it is generally believed that the ring of lymphoid tissue in the pharynx acts as a barrier which protects the lower air passages by catching up bacteria which enter the mouth or nose. Many organisms undoubtedly do enter the tonsil crypts, but in vicw of the experiments reported above ${ }^{2}$ it sccms that such invasion occurs rather in spite of the mechanism which tends to spare the tonsils than as a heneficial event. Few would claim nowadays that the tonsils which have come to be regarded as notoriously injurious foci of infection serve any uscful protective function.

While the flushing mechanism outlinicd above undoubtedly constitutes the major or first line of defence against eolonization of bacteria in the buccal cavity, there are other factors to be considercd. The bactericidal action of the saliva is certainly of some importance. While the literature on this subject is eonfusing and unsatisfactory, ${ }^{6}$ as it deals only with test tube experiments which can liardly be applied to actual conditions in the mouth, it has been possible to show in the ease of at least one variety of bacteria-sarcina luten-that the saliva exerts a rapid actual destructive action in viro: killing the organisms within fiftecn musutes to one hour. ${ }^{7}$ It may be that other organisms are similarly destroyed, but even in cases in which there is no true bacterieidal

* We úse this term to indiente a biologic renetion between the organiem and the host which allows the growth in silu of the former. 
action there may be an inhibitory or baeteriostatic cffect. This is a eomplex question of great interest which requires much more study. It scems of particular importance beeause even a slight lacteriostatic effect may be adequate to inhibit the activity of a foreign organism until it enn be eliminnted by the flushing mechasism.

The reaction of the mouth seeretions must be eonsidered apart from thcir other qualities. Recent work has brought out the tremendous importance of hydrogen-ion concentration in the growth of bacteria and of tissues in vitro, ${ }^{8}$ and the question is raiscd whether reaction is not influential in favoring or inhiliting growth in vivo as well. It is suggestive that the reaction of most salivas $-p^{\prime \prime} 6.0-p^{\prime \prime} 7.3-$ is more acid than that which lias been found to be the optimuin for growth of pathogenic baeteria such is pneumoeoci, streptococci, and influenza bacilli in the test tuhe-nanely $p^{\prime \prime} 7.4-p^{\prime \prime} 7.6$. In fact the $p^{\prime \prime}$ of the majority of human salivas is greater than that whieh allows initiation of pncumoeeus growth at all in artificial media. ${ }^{10}$ One may then safcly conclude that the rcaction of the mouth secretions docs not favor most foreign bacterin; to what extent it actually has un inlibitory efleet of practical importance cannot be definitcly stated as yet.

Still another possible faetor is that of antagonistie aetion against foreign bacteria by the normal mouth flora. Test-tube experiments seem of little value in settling this point and expcrimental appronch is difficult, but occasional observations indicatc that one organism may dislodge another. Patient F. yielded licmolytie influenza bacilli in large numbers on thrce sueeessivc eultures from the pharynx. Tho days after the last examination le developed an acute tonsillitis. Thereafter on numerous cultures unale over a period of two months hemolytic streptococei were present in almost purc culture, but hemolytic influenzal hacilli were no longer found. Patient $A$. on first culture showed mixed throat flora. On the second and third cultures the plates were eovered with Friedlinder bacilli. There had been no clinienl reaction. 'lWo more cultures were made, using a system of dilutions so that only twenty-five to fifty colonies of Friedlinder bailli were present on each plate. Even with this dilution, whieh prol)albly climinated overgrowth on the plates, no other organisms v'ere prcsent, indicating that they were largely or cntirely abscut at the sitc of culture. It may be therefore that a balance of power annong the various inhabitants of the mouth is an aeecssory factor in inlibiting the growth and colonization of foreign invaders.

Although the present diseussion coneerns itself with the means wherelyy colonization or establishment of growth on respiratory inucous mcmbranes is prevented, for the sake of completeness onc nust mention the last line of defence, namely, the protective activi- 
ties of the body fluids and cells. This point is brought up beeause there is evidenee that even without production of discasc occasional penetration of intact mucous membranes by baeteria may oceur." Whether in sueh eases at least a physiologic laek of eontinuity cxists is a mueh-disputed aeademic question, which need not be diseussed in the present conneetion. The point of importance is that cven should a forcign organism escape elimination of the flushing meehanisin-caught up, let us say, in a crevice of the mucous membrane-there still remain possible modes of effeetive disposal.

The Nasal Passages. While the protective mechanism of the mouth consists mainly of elimination, that of the nose operates especially by prevention of invasion; anatomie considerations are unimportant in the former, essential in the latter. Entry of bacteria into the nose follows almost always the inhalation of bacteria-laden dust or droplets; direct introduction, which is the nsual event in thic case of the mouth, rarcly occurs. If one considers the structurc of the nasal passages it is apparent that no direct open path exists in the line of the air currents but that such currents immediately impinge upon the turbinated bones. Furthermorc, thesc are so construeted that the stream of air is not only broken up hut is deflected in numerous direetions. A satisfactory demonstration of this fact is obtained by study of frontal sections through the nasal passages at various levels. As a matter of fact, most of the inhaled bacteria are arrested (probibly by the network of moist vibrissa) very near tbe anterior nares, as shown by Hasslauer, ${ }^{12}$ Thompson and Hewlett ${ }^{13}$ and others, who found large numbers of organisms at the nasal orifiees and few or none in the deeper air passages. But inasmuch as the nasal mucosa is covered with a film of mucus, any organisms whieh to penetrate arc promptly caught up and rapidly swept by the current of the eiliated epithelium toward the planrynx and esophagus. Thompson and Hewlett noted the speed of the eiliary eurret in the frog's pharynx to be as great as one inch per minutc, and by actual experiment we have found that organisms plaeed in the nose may be recovered from the pharynx after as short a space of timc as ten minutes. In summary, then, wc have an effective self-cleaning filter which purifies the air of bacteria before it enters the lungs.

Whetlier or not other clements enter into the protective meehnnism of the nasal passages is uneertain. Thompson and Hewlett obtained evilence that hacili is prodigiosus was destroyed in the nose, and eonclude without justification that few or no baeteriu introcheed into the nares ean reach the pharynx alive. There are also ecrtain incompletc and dubious experiments on reeorl as to the luctericidal action of the nasal seeretions' $i$ in vitro. 'Ilis part of the subject requires much further study beforc final statemeits ean be made. 
The Lungs. 'Tlic question of how the lungs arc guarded against infeetion is one of great intcrest, and in considering this matter our main point of approueh must be the ontstanding faet that in healtl few or no bueteria are present below the larymx. Whilc direct evidence from human beings is not readily olstainable, cultures made from the lungs of healthy auimals are almost uniformly sterilc. 'The most significant observations on this point with which wc are familiar arc those of Hcuer. ${ }^{\text {ts }}$ 'This observer, in the course of experimental excision of the lung in dogs, uade numerous cultures from the bronehial stump. In no ease were any organisms found. On the otler liand it is known from postmortem appearances tlant dust and carbon and metal particles do reach the lung, and it seems very likely that some few bacteria are introdueed as well. The history of this question is an interesting onc and many observations are on record which secm contradictory. I'aul, ${ }^{16}$ Neuninger $^{17}$ and Quesnil ${ }^{18}$ give a comprelensive review of tlic literature on the subject of the baeterial content of thic normal lung and attempt to reconcile tlic diversc findings of various writers. When onc considers that some studies wore made a considerable lengtl of time after death, some in cascs in which therc liad becn a long agonal period, and that in others the subjects were animals who burrow in fodder and inhale henvily bactcria-laden dust, it is clear that onc can draw no final conclusion as to the usual statc of affairs in man. It seems ccrtain, lowever, that in liealth and under avernge conditions of dust cxposure it is only the occasional organism which penetrates below the larynx. It appears then that the protective mechanism of the lung includes two main factors: (a) An anatomic structure which. euts off most of the organisms from the inspired air, and (b) a process which destroys or eliminates the few which do penetrate.

The anatomic element seems of greatest importance. As pointed out abovc the entering current of air, whether through nose or mouth, is deflected against complex mueous-covered surfaecs which eatclı up baeteria and act as filters. In regard to the question of low many baeteria actually do pass these barriers the experiments of Paul ${ }^{16}$ are of special significanee. This observer placed rabbits in a glass elamber into which $n$ suspension of bacillus prodigiosus was sprayed. After one-half hour of this treatment the animals were killed and cultures were made from the lungs under proper preeautions. Prodigiosus was invariably found, sometimes as many as 500,000 eolonies in part of one lung. By an ingenious caleulation, Paul reached the conclusion that 4 per cent of the inspired organisms had reacled the lung, and reasoned further that under spontaneous conditions a similar fraction of the inspired bacteria might penetrate. We are not convineed that this reasoning is eorrect-probably there is a proportionate deerease in tlie number of bacteria reaching the lung as the number 
in the air decreases, but none the less the fact remains that the filter is not a perfect one and that at tines organisms do actually penetratc beyond the larynx. Paul also showed by a rather artificial experiment in which he introduced a foamy suspension of prodigiosus into the mouths of rabbits that droplets formed by the bursting of bubbles in situ might be inhaled, as indicated by subsequent recovery of the organisms from the lung. In actual life the bactcrial content of the air is variable. In dusty rooms it may be as great as several hundred thousand per cubic meter, but this is unusual. The chances, therefore, of pathogenic bacteria reaching the lungs of normal people by direct inhalation are slight.

The main factor then in the protective mechanism of the lung is a lighly effective but not infallible filter. What is the fate of the few organisms which do pass the larynx in health? Three possibilities must be considered. The bacteria may be removed, they may be destroyed in the lung or they may set up disease.

The trachea and larger bronchi are lined with ciliated epithelium which sweeps toward the larynx. We know that inhaled dust is carried up by this process and expectorated mixed with mucus; doubtless bacteria are eliminated in the same way. That this is not the only element involved in removing bacteria from the lung is indicated by an experiment such as the following: Paul sprayed rabbits with prodigiosus and found that after twentyfour hours only $1 / 35000$ as many colonics were present in the lung as after the treatment, wherens in a similar experiment with subtilis spores $0 / 11$ of the number originally inhaled could be recovered after twenty-four hours. This would suggest somc other process besides a simple mechnnical removal. Simultaneous cultures from lungs and bronchial nodes ${ }^{18}$ indicate that many bacteria are removed by lymphatic drainage, and finally some organisms finding themselves in unfavorable surroundings may die in situ in the lung.

In summary, then, in health a very effective protective mechanism exists which operates against the colonization of bacteria in the lung. The main element is a filtration system whicb allows only few organisms to enter. These, unless they produce disease, are eliminated by the ciliary current, by dying in silu or by being carried off through the lymphatics.

Above we have sketched briefy the modus operandi of the protective mechanism against the colonization of bacteria in the respiratory tract, recognizing that our knowledge is still in the most rudimentary stage. The essential point, however, scems to be a system of mecbanical filtration and flushing aided by influences whicl 1 temporarily arrest the aggressiveness* of forcign

* This term is not used here in the teehnieal sense. 
organisms (reaction and bacteriostatic cflect of saliva, antigonistic action of moutl baeteria) until they can le removed.

So far we liave stated the case altogether in favor of the loost and against the invader. But experience shows that the protective meclıanism, while theorctically adequatc, often loreaks down in actual faet with consequent colonization of foreign bacteria and production of disease. It seems pertinent, thereforc, to cxamine the matter from the other side and to analyze the factors which lend to failure of the protective mechanism.

1. Dosage. There exist eertain baeteria of such virulence that a single cell may sufficc to infect a susceptible animal. On the otler liaud we find organisms of suel a nature that no number however great secms capable of setting up disease. In the vast majority of cases, however, it is dosage which is the determining factor in experimental infection. Numerous observations indicate its inportance in luman disense also. We may perliaps tlink of infection in terms of a balance struck betwcen the race and various types of bacterial invaders whicl tends to kcep up an avernge incidence of jnfectious disenses among large groups of pcople. But in the individual case an overwhelming dose of organisms may regularly produce disease. It seems altogetler rcasonable to suppose that the protective mechanism of the respiratory passages, unless it were perfect, in its aetion would bc nore eflective agninst a sinaller than against a larger dose of foreign pathogens. While single organisms successively introduced might be disposed of thousands of times before a weak point in the defence could be taken advantage of, some one or anotlier of a thousand organisms simultaneously introduced inight find favorable conditions for colonization or invasion even thougl all the rest of the group were eliminated. It is likely therefore that, other things being equal, dosage is of importance in explaining certain instances of breakdown of the protective mechanism.

2. Anatomical Features. In the experiments which were made on the fate of cliarcoal particles introduced into the inouth it was noted that anatomical variations frequently led to a disturbance of the normal currents of removal. In one instance it was possible to watch for several hours a small mass of carbon particles which had been arrested above a bit of protruding lymphoid tissue on the posterior pharyngeal wall. Furthermore, particlcs and bacteria unst be frequently caught up in thc tonsillar crevices despite their relntively protected position. It may well be then that an organism which would be hammless if promptly eliminated may be enabled to unfold pathologic activity if arrested in the thront for any length of time.

3. Lag. An old observation in bacteriology is to the effect that a single organism inoculated into a flask of broth may fail to grow, wliereas a larger inoculation may result in profuse develop- 
ment. Further study of this phenomenon has shown that the various nombers of a culture are not equally viable at all ages aul that seneseence sets in early. If such seneseent organisins are transferred to a fresh medimm a latent period exists before aetive growth is again resumed by the culture as a whole. This phenomenon of lag has been carefully studied by Cliesney, ${ }^{19}$ who has worked out its laws espceially in the-case of pneumococeus. But pathogenic organisms as they enter the body from certain outside solırces are probably not always in an active vegetative state. When dried in clust or on objects they usually assume an inaetive or restiug form. It is fair to conclude, therefore, that inany pathogenic organisms as they enter the respiratory passages are in a state of greater or less inhibition. Such inhibition may be inportant in allowing their removal before aetivity is resumed. Conversely, if the organisin enters the mouth whilc in an actively vegetative statc its chances of colonization should be greater. Such a condition of affairs would apply especially to organisms transferred directly by cough through the air from onc individual to another. It is of interest that in epidemics of acute infections such as those which occurred in the army eamps one was dealing with a concentration of individuals and lence with a rapid transinission of organisms by very direct routes, indienting that a highly vegetative stnte of the bacterin existed.

4. Injurics. Ierhaps the most important factor lending to $n$ breakdown of the protective mechanism is some type of injury. Before taking up this point, however, a few words must be said about virulence and resistance.

Virulence. As a rule this term has been loosely used to indieate that the organism in question is produeing a more or less severe and highly contagious form of disease. More exact definition is however necessary; in other words, does a highly virulent organism possess intrinsically any greater invasive power than a less virulent member of the same species, and if the two were deposited on a perfeetly intact and bealthy mueous membrane would the one be able to invade and produce disease while the other could not? It seems that definite evidence of any such difference is lacking, but that in the case of the virulent organism a much slighter injury or defeet and perhaps an injury or defeet of a different sort is adequate to allow invasion. In the ease of an extremely virulent organism one ean picture the requisite injury being so slight as to approach zero. The point may best be brought out by a speeific example such as streptoeoccis infection. Under ordinary conditions the streptococeus is elearly a sccondary invader. Its role in terminal infeetions, in scarlet fever, in mensles and in influenza may be mentioned. Here it unfolds its activities on tissue damaged by an independent primary process. During the war, following the rapid and extensive passage of strep- 
toeoeei through large numbers of patients with measles, strains appeared whiel finally on superficial serutiny seemed able to prodluee prinary disease. "It seems mueh more likely, however, that these exalted strains were simply able to take advantage of a minute lesion, perhaps a minute meehanieal injury of the mueous membranes, which under ordinary eireumstances would not suffice to allow the entry of an organism of average virulenee. This iliea is supported by the elinieal observations of every type of transition between the streptocoeeus as an obvious secondary invader, and the streptoeoceus as an apparent primary invader. The situntion may be diagrammed as follows:

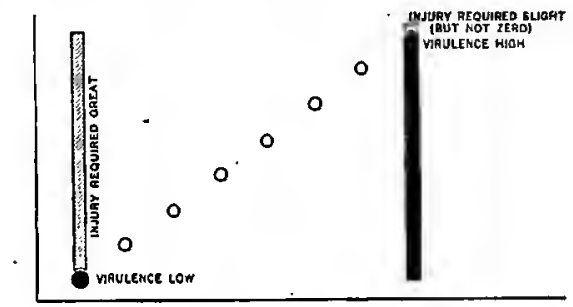

In further support of this idea the following facts may be mentioned: (a) The usual prompt elimination of foreign organisms naturally or experimentally introduced into the upper air passages; (b) the corroloorative evidenee of the rarity of the produetion of eertain disenses by direet contaet such as lobar penimonia; and $(c)$ the faet that the ineidence of a disease due to a highly "virulent" organism may be lower than that of a disense dhe to a less "virulent" one. For example, the incidenee anong pneumonia eases of type III infection is only nbout 10 per cent with a mortality rate of 50 per cent, whereas type 1 infeetions, which make up 25 to 30 per eent, of the whole, lave a mortality of only 20 to 35 per cent..$^{20}$ Furthermore, the type 111 organism is more widely distributed among the population in general than type l. Clearly the invasive power of these organisms does not run parallel with the severity of the infeetion produeed by them.

In summary, then, while the virulence of an organism may establish the inortality rate among those infeeted, and may to some extent cleternine the ineidenee of infeetion in so far as the highly virulent organism may take arlvantage of a slight injury to the host so that it can invade, in the last analysis the produetion of disease seens to be marle possible by an injury or defect which is more or less independent of the organisn. This generalization seems to apply to the common respiratory pathogens suchl:Is pneumoeoceus, streptococeus, meningoeoecus, and the influen\%a 
baeillus. Whether other viruses sueh as the hypothetical ones of the acute exanthematn can produce their own injury requisite for invasion is still uncertain.

Types of Injury Important in the Production of Respiratory Infection. Such injuries may be mechanical, thermal, elıemical or infectious.

A. Nechanical Injuries. Purely mechanical injuries probably play ouly a uninor part in facilitating infection. 'Tle mucous incmlranes, however, undoubtedly suffer eonstant slight traumati which inay crate portals of entry for higlily virulent organisms. Such lesions mny well account for many sepses of so-called cryptogenetic origili. They also undoubtedly play a part in the produetion of erysipelas. We have observed thrce cases of septicemia directly following the mechanical clennsing of tonsil erypts during the course of acute tonsillitis. Blake" was unable to produce pneumonin in monkcys by placing virulent cultures of pneumocoeci in the thront, but after injuring the trachen with a needle puncture invasion became possible. It is well established that postoperntive lung alsseess is due to the forcible inlulation of bacteria-laden bits of blool clot, following the elimination of the protective reflexes by the anestlictic. Disturbances of the eilin-bearing epithelium of the nose by operative measures often lends to subsequent elironic inflamnatiou with colonization of bacteria. Finally, as an instance of meelianical disturbance of the baeterin eliminative meclianisin, an observation made by us in a patient with bullunr palsy may be recorded. In this case sarcina luten plaeed on the tongue was not removed by the usual suetion currents but remained confinerl to the site of inoculation during the whole period of the experiment.

B. Thermal Injuries. The question of the relation of cold to respiratory infection is of interest. The recent thorough experiments of $\mathrm{Mudd}^{22}$ and his associates indiente that thermal variations leal to marked vasomotor and secretory clinges in the upper air passages. Tlicse writers bring a certnin amount of evidenec ${ }^{23}$ that the bueterial flora may be modifies following sueh reactions and give an important lead for further study.

C. Chemical Injuries. Chemieal injuries may undoubtedly produce lesions which disturb the normal eliminative mechanism and allow hncterial invasion. Two promient examples may be quoted: War-gas poisoning, ${ }^{21}$ if of any degree of severity, is followed by broncliopneumonias and listologie studies of the tissues slow the bacterin aetually invading the mueous surfaces denuded of their protecting epithelium. l'oisoning with certain arsenicals allied to arsphenamine is accompanied by a scvere erythema of the respirntory mucosa. This is soon followed by a bronchopneumonia elearly secondary to the chemieal injury. We havc observed tliree instances of this condition.

D. Infection. In this group falls perhaps the most importint kind of injury which leads to secondary bacterial invasion in the upper respirat ory tract. 'The role of moasles, searlet fever, influenza, 
smallpox and the exanthemata in gencral in allowing secondary infection is notable. In these diseases the "erythema" of thic respiratory mucosa is associated with a disturbance of the norinal protective mechanism following which sccondary infections with various organisms readily occur. Olitzky and Gates ${ }^{25}$ hring cxperimental support for this idea in the case of influenza. The common cold frequently draws in its wake a series of obvious minor secondary infections, and perhaps just as often serves as the predisposing factor for more serious infections. A eareful clinical study of such discases as lobar pncumonia and meningitis might disclosc such preliminary injuries.

5. Adlaptation. However much one may try to reduce tlic proteetive mechanism to a conerete basis there still remains a faetor to bc considered, namely, inlerent adaptation of eertain bacteria to growth on hunnan mucous membrancs. In another place we have presented evidence that some bacteria not members of the normal flora which arc potentially capable of producing discnsc may become unorc or less complctely adapted to free growtl on normal mucous membranes. ${ }^{26}$ 'This is truc of influenza bacilli, green-producing streptococci and probably many otleer bacteria. Iurder sucl conditions the orgnnism is not eliminated but is at linnl over long periods of time. Then if proper accessory conditions arise invasion and discasc may follow.

Discussion. The proble!n of infection may be approaclicd from (vither of two standpoints - that of infection in groups of pcople ol that of infection in the individual. Under the former licad there are to be considered the broad general questions of the spread and ineidence of disease-the nature and course of cpilemics, the seasonal occurrence of various diseases, and their gcographical distribution. A grcat stock of information in regard to tliesc unatters has bcen accumulated through the recording of gross fucts and to a lesser extent by experimental studies of cpidcmies in animals, but the final determination of the laws governing infection lias not yet been achicved. Contradictions eonstantly cone up. In the case of a paudemic of influcmza, for example, it sccms established from the general sepunee of events that we are dealing with $\mathfrak{a}$ disease dne to a living virus and onc which is highly contagious. But when one attempts to explain the details of its sprend. insurnountable difficultics immediately arisc. The ligh ineidencc of the disease in certain localities among special groups of pcople with the sparing of others, the sparing of particular individıals for a considerable length of time (despite constant exposure) with ultiinate infection, and the question of the sporadic casc may be mentioned as examples of the difficulties which present themselves. Again, in the rase of lobar pncumonia, despite the evidence in favor of transunission by carriers or dust, these general principles scem inadequate in working out the origin of individual infections.

Asille from suel broad considerations we have to deal with. 
the prolden of infeetion in the individual, and leere a different approach must lie ised. The general facts of epidemiology tell the number of people in a commmity likely to be affeeted by a certain disease under given conditions, a solution of the problem of infeetion in the individual will tell why $\mathrm{A}$. is affeeted rather than B. and C. ratlier than D.

In an attempt to elarify this latter plase of infection with referenee to respiratory disense the ahove nnalysis is presented. It has seemcl profitable to avoid, as far as possible, such vague terms as virulence and resistance and to reduee the facts to concrete tenns. 'The inost general conelusion is to the effeet that there exists in the respiratory passages-, nose, throat, mouth and lungsa mechanism which tends to eliminate foreign partieles and baeteria.

It is also clear that this eliminative mechanisin lias many imperfections and that in actual practice it often breaks down; it should be thought of rather as $n$ tendency than as a rigidly effieient proeess, as relative and not as absolute, difl'ering with diflerent organisms and with a lost of secondary conditions.

Again, it seems unwise to go too far in assigning purposcful protective qualities to the eliminative mechanism, and we wish morely to stress and to classify facts whieh may be helpful in explaining the means whereby colonization of baeteria is prevented or favorel. A word of speenlation may lowever be allow:uble. The clnssical vicwpoint in regarl to recovery from infection, or protection aguinst infection, based on theories of hunoral immunity, assumes a positively destructive aetion in disposing of foreign bacterin. It is now becoming more and more evident that the simple absence of favorable eircunstanecs for the organisn may be just as effective as any positively destruetive aetion. T'esttube experiments are very clear on this point. P'neumocoeei, for example, when growth is once started may multiply in broth until a limiting reaction of $\mathrm{p}^{\mathrm{n}} 5$ is reached. Growtl cannot, however, be initiated below $\mathrm{p}^{\mathrm{n}} 7$ in the same medium. In studying the aetion of dyes on breteria it has also been shown that inlibitory or bacteriostatic elleets are perhaps of as much importanee as aetual baeterieidal action. It seems that this principle should be extended to human infeetion and that the respiratory protective meehanism is perhaps largely a matter of absence of favorable conditions for the foreign organism rather than any positively destruetive process, although sueh aetion may be shown in certain instances. 'The main point, then, which we wish to make is the following. It has usually been assumed that the presumption was in favor of the invading organism and that the body was obliged to eall forth special protective proeess to prevent infeetion. Now it is elear that the mierörganism is, on the wholc, at a disadvantage and that no special response is, as a rule, required to dispose of it, but that speeial favoring cireumstanees for the organism must be present hefore infectionican take place. 


\title{
REPERENCES
}

1. British Med. Jour., July 18, 1808 (quoled hy Thompson and Huwlett).

2. Bloomfield, A. L.: The Circulation of Forcign Particles in the Mlouth, Ast. Hev. Tuberc., 1922, 6, 903.

3. Bloomfield, $A$. L.: The Circulation of Bneterin in the Mlouth, Bull. Johns Ilopkins Hosp., 1922, 33, 145.

4. Bloomficld, A. L.: The Upper Air Passnges as an Environment for Bacterial Growth, Am. Rev. Tulere,, 1929, 4, 247.

5. Crowe, S. J.: The Relatioo of Tonsillar aod Nasopharyngeal Infections to General Systemic Disorders, Bull. Johng Hopkins Hosp., 1917, 28, 1.

0. See Sanarelli: Centralbl. f. Bacteriol., 1891, 1 Alit., Bd. 19, 25. Barnes, B. S.: Tr. Chiengo Path. Soc., 1907-00, 8, 249.

7. Bloomfield, A. L.: The Fate of Baclera Introdueed into the Upper Air l'assages, Bull. Johns Hopkins Hosp., 1010, 30, 317.

8. See Avery, O. T.: Jour. Exper. Med., 1910, 29, 215. Fischer. Albert: Jour. Exper. Med., 1921, 24, 447.

9. Bloomfield, A. L.: The Reaetion of the Snliva, Bull. Jolıns Hopkins Hosp., $1021,31,118$.

10. Avery, O. T.: Jour. Exper. Mled., 1919, 30, 359.

11. See Zinsser, Hans: Infection and Resistanec, 2d ed., P. 13.

12. Hasslaucr: Centralbl f. Bakteriol., 1000, 1 Alst. Ref., Bd. 37, 1.

13. Thompson and Herrlett: Lancet, 1890, $1,86$.

14. Seo Wurtz and Lermoyez: Am. desmal. de l'orellle, 1893. And Calvino, V. E.

M.: Arch. Ital, di Otolog., ete., 1891, Bd. 10, 25.

15. Heuer, G. J.: Personal communication.

10. Paul, Lud wig: Ztsclir. f. Hyg., 1002, 10, 408.

17. Neuninger, O.: Ztgclir. f. Hyg., 1001, 38, 04 .

18. Quesnil, U.: Ztschr. f. Hyg., 1902, 40, 505.

19. Chesocy, A. M.: Jour. Exper. Med., 1910, 24, 387.

20. Avery, Chickcring, Cole and Doebez: Monographs of the Rockefeller Institute for Medical Research, No. 7. Aeuto Loliar Pneumonia.

21. Blake, F. G. nod Ceeil, R. L. Jour. Exper. Med., 1920, 31, 403.

22. Mudd, Goldman and Grant: Jour. Iofeet. Dis., 1921, 34, 11.

23. Mudd, Grant and Goldmann: Jour. Infect. Dis., 1021, 29, 151.

24. Winternitz, M. C.: Jour. Exper. Med., 1010, 29, 537.

25. Olitzky, P. and Gates, F.: Jour. Exper. Mfed., 1021, 34, 1.

20. Bloomfield, A. L.: The Signifieance of Henolytie Influetra Bacilli, Bull. Johns Hopkins Ifosp., 1021, 22, 378.

\section{TWO HUNDRED SYPHIITIC PATIFNTS WHOSE CHIEF COM- PLAINT WAS "STOMACH TROUBLE;" AN INTERPRETATIVE ANALYSIS OF THE DIAGNOSIS OF SXPHIIS IN CON- SULTANT MEDICAI PRACTCE.}

\author{
By Jolin H. Stokes, M.D., \\ PROFESEOL OF DEIRIATOLOOY AXD BTP!HOLOOY, ALAYO FOUNDATION OILADATE \\ SCIOOL, UNIVERGITY OF MINNEBOTA, \\ AND \\ Pulup W. Brown, M.D., \\ FEILOW IN SIBDICINE, THE MATO FODNDATION, NOCHESTEn, MINAESOTA.
}

(From the Section on Dermatolopy nnel Syphilology, Mnyo Clipic.)

CAno\%, in the second edition of Difforeminl Dingmosis, directed the attention of the profession to dispepsin as a medicnl complnint, 